\title{
Effects of phytoplankton physiology on export flux
}

\author{
L. Alex Kahl ${ }^{1,2, *}$, Assaf Vardi $^{2}$, Oscar Schofield ${ }^{1,2}$ \\ ${ }^{1}$ Coastal Ocean Observation Laboratory, and ${ }^{2}$ Environmental Biophysics and Molecular Ecology Laboratory, \\ Institute of Marine and Coastal Sciences, Rutgers University, 71 Dudley Road, New Brunswick, New Jersey 08901, USA
}

\begin{abstract}
Estimates of phytoplankton sticking efficiency $(\alpha)$ were made in the laboratory within a $1500 \mathrm{l}$ annular flume mesocosm over the initiation, maintenance and senescence phases of a bloom of the diatom Thalassiosira pseudonana. The spatially weighted mean turbulence kinetic energy dissipation rate in the annular flume was comparable to values found at the ocean's surface on a calm day. The $\alpha$ of T. pseudonana varied as a result of physiological state, and ranged from $0 \pm 0.08$ during the bloom initiation to 0.26 and $0.73 \pm 0.16$, respectively, during bloom maintenance and senescence phases. During the periods of high $\alpha$, physiological changes included (1) diminished phytoplankton photosynthetic quantum efficiency, (2) an increase in super-oxide dismutase protein expression, reflecting oxidative stress, and (3) the induction of a biochemical cascade initiating autocatalytic programmed cell death. Additionally, during the period of high physiological stress on the diatoms, there was an increase in the presence of transparent exopolymer particles and bacteria. Applying a variable $\alpha$ to a 1-dimensional export flux model shows that carbon export can be increased by at least 2 -fold compared to simulations assuming a typically modeled value of $\alpha=1$ (100\% sticking efficiency). The model using a physiologically dependent $\alpha$ had a low initial sticking efficiency that allowed a significant increase in the critical concentration of algal cells. Such an increase in the number of cells during bloom initiation followed by an increase in $\alpha$ during the maintenance and senescence phases resulted in enhanced export fluxes during the latter, 'stickier', stages of the bloom.
\end{abstract}

KEY WORDS: Phytoplankton - Export flux · Sticking efficiency · Transparent exopolymer particles - Photosynthetic efficiency · Oxidative stress $\cdot$ Programmed cell death $\cdot$ Mesocosm

Resale or republication not permitted without written consent of the publisher

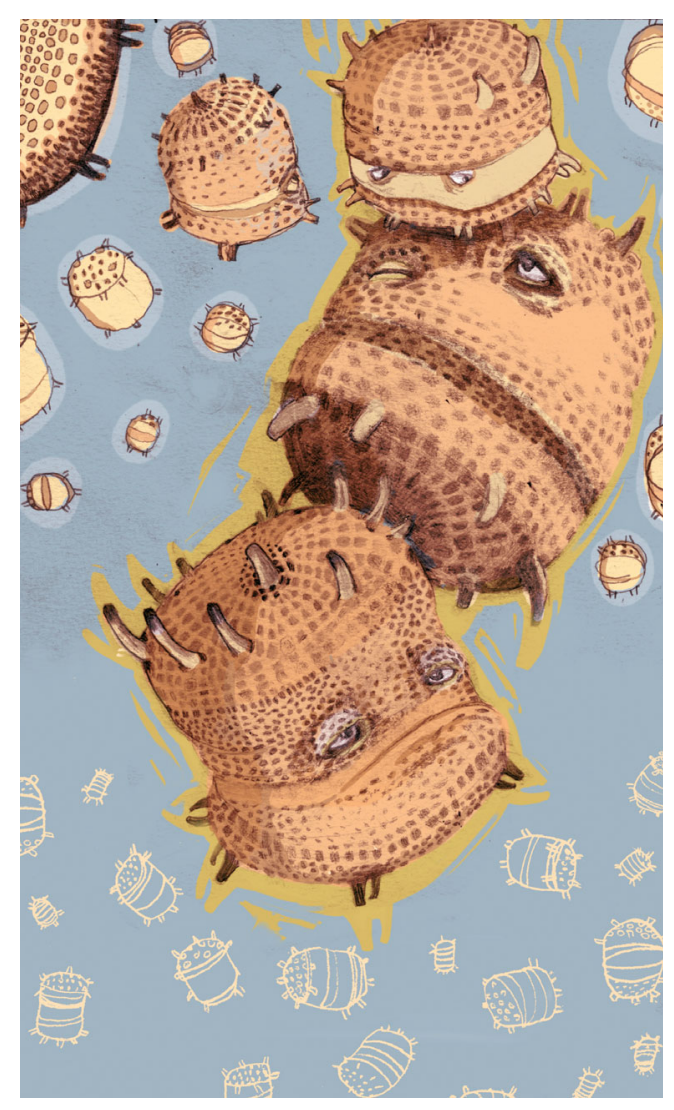

Diatoms in distress.

Illustration: Nivi Alroy

\section{INTRODUCTION}

Annually, ocean primary production is responsible for half of the Earth's biologically fixed $\mathrm{CO}_{2}$ (Field et al. 1998). A variable, yet significant, amount of the organic carbon produced by primary production in the ocean's euphotic zone is sequestered into the deep sea via the biological pump (Martin et al. 1987). The flux of carbon and the efficiency of its sequestration are a function of the amount and form of particulate carbon present. The concentration of organic carbon at the ocean's surface is a critical determinant of 
the potential flux of particulate carbon to the deep sea (Fowler \& Knauer 1986). The form of the particulate carbon affects the sinking rate (Jackson \& Burd 1998) and the efficiency (Turner 2002) with which the particulate material is re-mineralized during its downward transport. The formation of marine snow, agglomerated marine particles that are often dominated by aggregates of algal cells, is a process that plays a significant role in determining the sinking rate and efficiency of the export flux of organic carbon. Genesis of marine snow generally occurs within phytoplankton blooms and the aggregates formed therein have relatively rapid settling velocities (Alldredge \& Gotschalk 1988). While coagulation models have approximated sedimentation within small phytoplankton blooms (Kiørboe et al. 1994), such models are less reliable when used to predict export flux following large-scale phytoplankton blooms (Hill 1992, Jackson et al. 2005). As a result, understanding the processes that regulate particle aggregation in the sea is central to improving our knowledge of large-scale oceanic carbon export.

Particle aggregation is a function of the size, collision frequency, and the sticking (or coalescence/coagulation) efficiency of the particles (McCave 1984). While collision frequency is a function of the turbulent energy within the water column, and the number and size of the particles present, the sticking efficiency of algal particles is believed to be a direct result of cellular exudation (Passow \& Alldredge 1995b), cell morphology (Kiørboe et al. 1990), and surface properties (Waite et al. 1995). For cell-to-cell interactions, the sticking efficiency (referred to as 'stickiness') is most often parameterized by $\alpha$ and is defined by the rate of coalescence, divided by the rate of collision (Hill \& Nowell 1990). Despite its central importance to particle aggregation, the variability in sticking efficiency is the least understood yet significant parameter of algal aggregation models (Hill 1992, Jackson 2005).

It is increasingly clear that sticking efficiency is a dynamic property driven by cellular processes in phytoplankton and bacteria (Alldredge et al. 1995). Previous studies demonstrate that sticking efficiency may vary by more than an order of magnitude (Table 1). Unfortunately, phytoplankton aggregation experiments are generally conducted at turbulence levels that are several orders of magnitude higher than the turbulence levels encountered during most phytoplankton blooms (Fig. 1, Table 1). The unrealistic energy levels in experimental systems are also partly responsible for the difficulty in reproducing aggregation phenomena of natural phytoplankton communities, as calm oceanic conditions are ideal for the formation of large aggregates following phytoplankton blooms (Alldredge \& Gotschalk 1989). Consequently, measurements of sticking efficiency under low shear conditions are extremely important and are expected to yield high values of sticking efficiency (Engel 2000).

Coagulation theory was used to estimate the sticking efficiency of a $23 \mathrm{~d}$ mesocosm monoculture of the diatom Thalassiosira pseudonana. In this mesocosm the sticking efficiency increased as the bloom aged. This increase in sticking efficiency was correlated with changes in the physiological state of the diatoms within the mesocosm. Variability of phytoplankton sticking efficiency, as was observed in this study, can result in enhanced bloom-associated particle export flux in the oceans.

\section{MATERIALS AND METHODS}

Mesocosm. The experiment was replicated in 2 separate mesocosms. Each experiment was conducted in a 15001 glass annular flume at Rutgers University Institute of Marine and Coastal Science. The flume has an

Table 1. Rates of fluid shear and algal cell estimated sticking efficiency in phytoplankton aggregation studies

\begin{tabular}{|c|c|c|c|}
\hline $\begin{array}{l}\text { Shear rate } \\
\left(\mathrm{s}^{-1}\right)\end{array}$ & $\begin{array}{c}\text { Sticking } \\
\text { efficiency }(\alpha)\end{array}$ & Device & Source \\
\hline 50 & 0.05 to 0.12 & Oscillating grid & Kiørboe et al. (1990) \\
\hline 0.03 to $0.05^{\mathrm{a}}$ & 0.88 & Settling chamber & Alldredge \& McGillivary (1991) \\
\hline 10 & 0 to 0.98 & Couette chamber & Kiørboe \& Hansen (1993) \\
\hline 5.7 & 0.001 to 0.13 & Couette chamber & Drapeau et al. (1994) \\
\hline 30 & 0.01 to 0.6 & Couette chamber & Kiørboe et al. (1994) \\
\hline 3 to 30 & $8 \times 10^{-5}$ & Couette chamber & Passow et al. (1994) \\
\hline 5 to 10 & 0.03 to 0.8 & Couette chamber ${ }^{b}$ & Dam \& Drapeau (1995) \\
\hline 8 to 10 & 0 to 0.7 & Couette chamber & Hansen \& Kiørboe (1997) \\
\hline 5 & $\sim 0$ to 0.03 & Couette chamber & Waite et al. (1997) \\
\hline 10 & 0 to 0.40 & Couette chamber & Kiørboe et al. (1998) \\
\hline 0.86 & $<0.1$ to 1 & Couette chamber & Engel (2000) \\
\hline $0.86^{\mathrm{c}}$ & 0.04 to 0.18 & Modeled ${ }^{\mathrm{c}}$ & Engel (2004) \\
\hline 1.3 & $10^{-4}$ to 0.37 & Rotating propeller ${ }^{\mathrm{a}}$ & Ackleh et al. (1995) \\
\hline 0.05 & 0 to 0.73 & Annular flume & This study \\
\hline \multicolumn{4}{|c|}{ 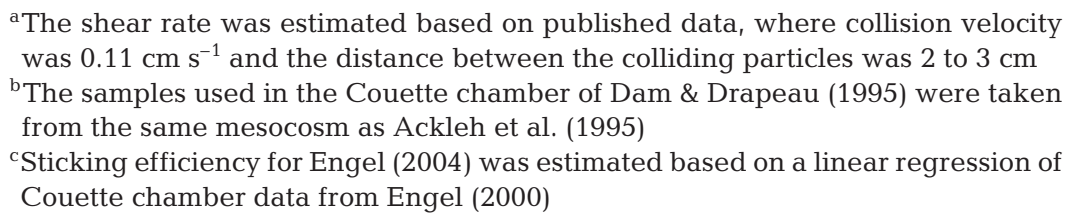 } \\
\hline
\end{tabular}




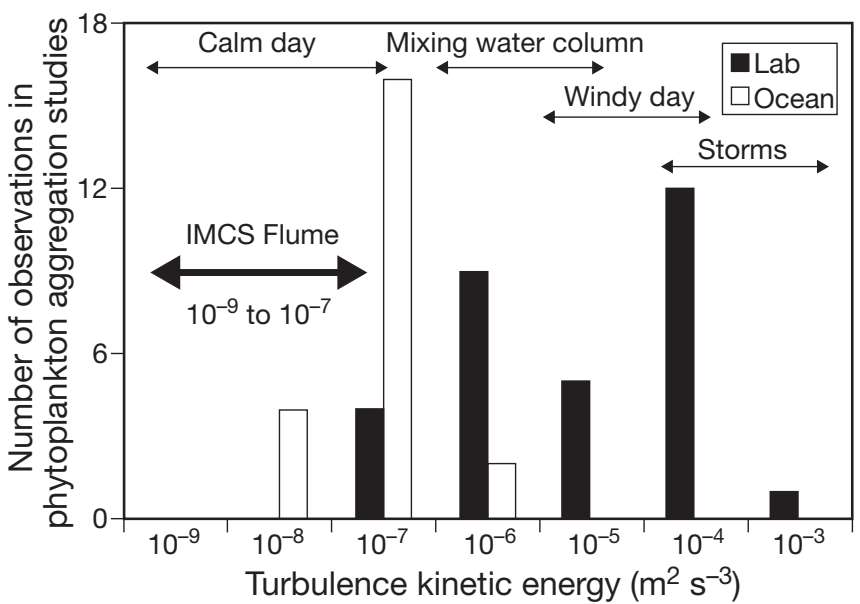

Fig. 1. Comparison of estimated energy levels during phytoplankton aggregation experiments in the laboratory and in the sea. Energy levels used in controlled environments (Lab) during aggregation studies were compiled from published data (Kiørboe et al. 1990, Riebesell 1991, Kiørboe \& Hansen 1993, Drapeau et al. 1994, Kiørboe et al. 1994, 1998, Passow et al. 1994, Alldredge et al. 1995, Dam \& Drapeau 1995, Hansen \& Kiørboe 1997, Karp-Boss \& Jumars 1998, Engel 2000, 2004). Ocean energy levels from field data (Alldredge et al. 1990, Passow et al. 1994, Jackson 1995, Logan et al. 1995, Passow \& Alldredge 1995b, Kiørboe et al. 1998, Passow 2000, 2002) during aggregation studies were estimated using Eq. (4) from Riebesell (1992). The range of energy levels in the annular flume used in this study are also presented

outer diameter of $3.99 \mathrm{~m}$ and a channel width of $30 \mathrm{~cm}$ (Hentschel 2004). During the experiments, the flume had a water depth of $42 \mathrm{~cm}$ and was illuminated with $24 \mathrm{~h}$ continuous light. The mean irradiance in the flume during the experiments was $172 \mu \mathrm{mol}$ photon $\left(\mathrm{m}^{2} \mathrm{~s}\right)^{-1}$ and was provided by Philips cool white plus fluorescent bulbs. The light field for advanced bloom stage conditions was lower due to the significant absorption of light by the dense phytoplankton populations.

The top, which rotates counter to the rotation of the bottom, drives the fluid flow within the flume. The flume temperature of both experiments was maintained at $17 \pm 0.3^{\circ} \mathrm{C}$ via a titanium heat exchanger located in the counter-rotating top of the flume. The flume rotation speeds and temperature were both controlled via the data acquisition and process control system CamileTG v.3.7 (Camile Products). The flume flow was characterized using laser Doppler anemometry using FLOware (Dantec Dynamics) and measurements made with a 2-axis Laser Doppler Velocimeter (LDV) (Dantec Dynamics). The LDV characterized 169 points across the annular flume channel to measure the horizontal and vertical velocity fields. There were 2000 validated measurements made by the LDV at each of the 169 fluid velocity sampling points. While the LDV has a precision of $10^{-5} \mathrm{~m} \mathrm{~s}^{-1}$, unpublished studies in the IMCS annular flumes show that the uncertainty of the velocity measurements are less than $10^{-4} \mathrm{~m} \mathrm{~s}^{-1}$ when at least 2000 samples are collected from a single point. Along-channel flow velocity was measured both vertically and horizontally by the LDV. Across-channel horizontal flow velocity (Fig. 2A) was characterized by using the continuity equation. To solve the continuity equation for across-channel velocity, we assumed that seawater in the flume was incompressible and that along-channel flow was not divergent. The LDV sample points were spaced at a maximum distance of $1 \mathrm{~cm}$ apart in the center of the flume channel, and at a minimum distance of $2 \mathrm{~mm}$ near the flume walls. Due to the acceptance angle of the LDV laser into the flume channel, we were not able to measure fluid velocities at heights less than $1.5 \mathrm{~cm}$ above the bottom of the flume. We calculated the shear rate $(\gamma)$ as the vertical gradient $(\mathrm{d} z)$ of the horizontal velocity $(u)$, along the flume channel. Where buoyancy effects due to temperature gradients are very small (as was the case in our annular flume), the mechanical turbulence kinetic energy (TKE) dissipation rate $(\varepsilon)$ is calculated as:

$$
\varepsilon=-\overline{u^{\prime} w^{\prime}} \frac{\mathrm{d} u}{\mathrm{~d} z}
$$

where $u^{\prime}$ and $w^{\prime}$ are the root mean square horizontal and vertical velocities. (See Table 2 for definitions of parameters and variables used in this study). The spatially weighted mean shear rate of the flume (Fig. 2A) was used as an input variable for the model of sticking efficiency, while the TKE dissipation rate of the flume (Fig. 2B) was used to provide a relative comparison with oceanic conditions.

The spatially weighted mean shear rate and TKE dissipation rate of the flume were $\gamma=0.05 \mathrm{~s}^{-1}$ and $\varepsilon=$ $8.87 \times 10^{-7} \mathrm{~m}^{2} \mathrm{~s}^{-3}$. Additionally, the principal location of shear generation in the flume is from the counterrotating top. Shear rates at the bottom of the flume, where algal cells and aggregates ultimately settled, were low. Over the duration of the experiments, the uni-modal shape and steadily declining $y$-intercept of the particle size distribution indicated that neither disaggregation nor Brownian pumping (McCave 1984) the coagulation of previously undetectable particles into measurable size classes-were significant processes in the mesocosm. Once the algal aggregates settled on the bottom of the flume channel, they formed a cohesive mat. Throughout the experiment, there was no visible re-suspension of algal material from the algal mat. The algal mat grew to an approximate thickness of $2 \mathrm{~mm}$ on the bottom of the flume channel over the course of the $23 \mathrm{~d}$ experiment.

Particle size distribution. The initiation (logarithmic growth), maintenance (decreased growth), and senescence (decreased population level) phases of a population of Thalassiosira pseudonana were followed over 

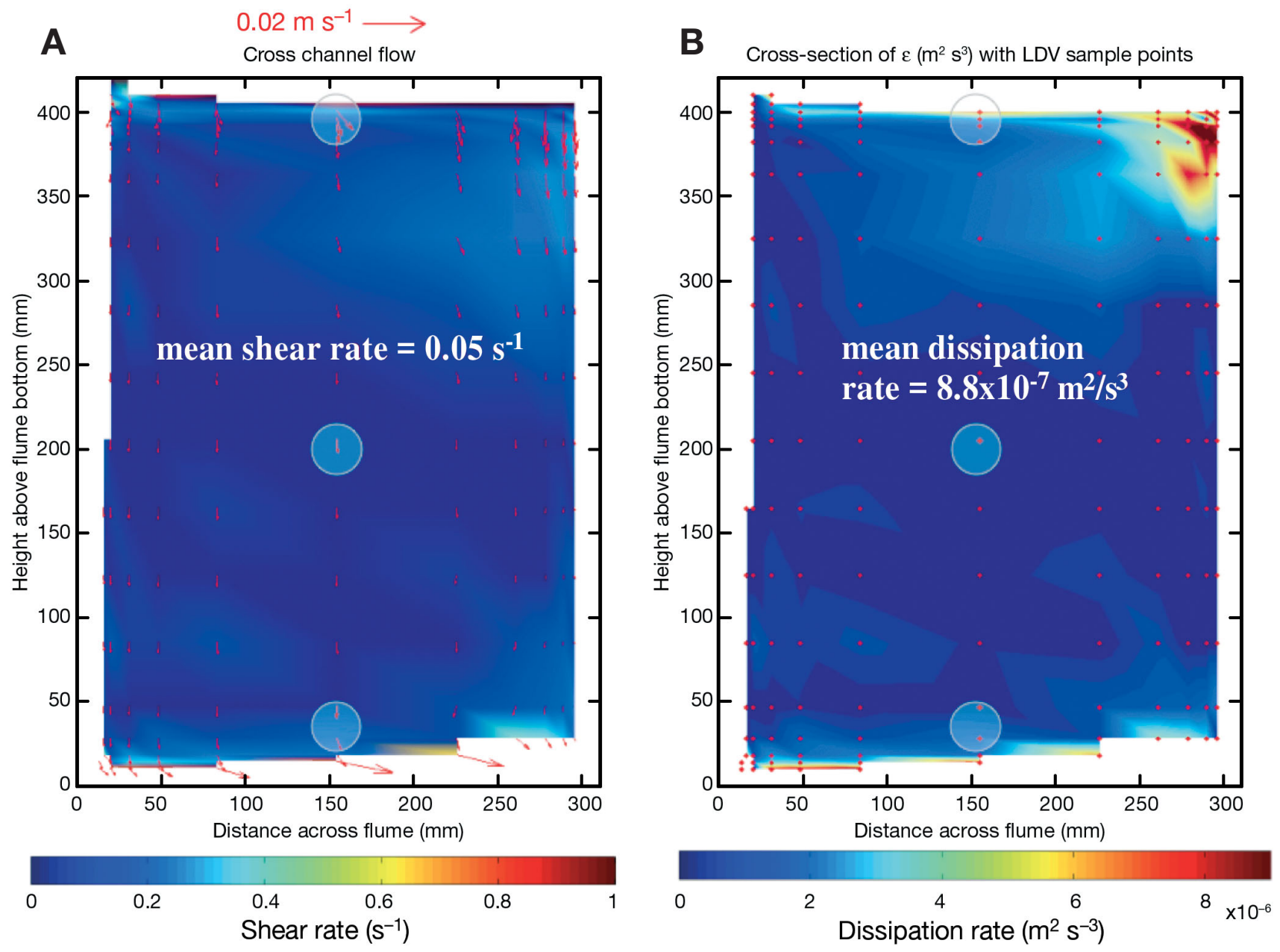

Fig. 2. Channel cross-section of flow characteristics of the annular flume at the Institute of Marine and Coastal Sciences, Rutgers University. Light blue circles depict the location and size of the 3 polypropylene tubes used to collect samples. (A) Shear rate and cross-channel flow vectors (with vector origins located at laser Doppler velocimeter [LDV] measurement points). (B) Turbulence kinetic energy dissipation rate, and LDV measurement points (red dots)

time within the flume. The bloom was initiated with a 201 inoculum of exponentially growing T. pseudonana cells into the f/10 medium in the mesocosm. During both experiments, triplicate $50 \mathrm{ml}$ samples were taken by hand once daily at 3 depths. The flume was sampled using a thin piece of PVC mounted with three $50 \mathrm{ml}$ polypropylene centrifuge tubes. The centrifuge tubes were modified such that both ends of the tube required a cap. The tubes were mounted on the PVC to collect samples at 2, 20, and $40 \mathrm{~cm}$ above the flume bottom. Within $5 \mathrm{~min}$ of removal of the samples from the flume, the particle size and volume distributions were characterized via aperture impedance. A Beckman Coulter Counter Multisizer II with a $100 \mu \mathrm{m}$ orifice tube was used to analyze all samples within 2 to $10 \mathrm{~min}$ after removal from the flume. If necessary, samples were carefully diluted using $0.2 \mu \mathrm{m}$ filtered seawater. During cell concentration and volume fraction enumeration, particle coincidence (the coincident passage of more than 1 particle through the Coulter counter orifice) through the Coulter counter aperture did not exceed $7 \%$ of the volume sampled. One drawback to the use of aperture impedance to determine aggregate size is the risk of particle break-up due to the high shear of the fluid as it passes through the orifice of the Multisizer (Gibbs 1982). We chose a $100 \mu \mathrm{m}$ Multisizer orifice for enumeration of particle characteristics because microscopic analysis from a preliminary flume-aggregation trial showed that aggregates of $T$. pseudonana cells (having an approximate equivalent spherical diameter of $3.5 \mu \mathrm{m}$ ) need to be comprised of about 25 T. pseudonana cells (equivalent spherical diameter of about $22 \mu \mathrm{m}$ ) to be adversely affected by high shear in the instrument orifice. Aggregates comprised of more than 25 cells were not observed during microscopy of a preliminary flume study. An aggregate comprised of 25 cells each having an equivalent spherical diameter (ESD) of $3.5 \mu \mathrm{m}$ would have a minimum 
Table 2. Definitions of parameters and symbols

\begin{tabular}{|c|c|c|}
\hline $\begin{array}{l}\text { Para- } \\
\text { meter }\end{array}$ & Description & Units \\
\hline$C$ & Concentration of cells & cells $\mathrm{cm}^{-3}$ \\
\hline$C_{\mathrm{cr}}$ & Critical concentration of cells & cells $\mathrm{cm}^{-3}$ \\
\hline$i, j, l$ & Particle size distribution section indices & \\
\hline$L$ & Characteristic length scale & $\mathrm{m}$ \\
\hline$m$ & Biomass & $\mathrm{cm}^{3}$ \\
\hline$Q$ & Sectional particle volume & $\mathrm{cm}^{3}$ \\
\hline $\operatorname{Re}$ & Reynolds number & \\
\hline$S$ & Number of sections & \\
\hline$u$ & Horizontal fluid velocity & $\mathrm{m} \mathrm{s}^{-1}$ \\
\hline$u^{\prime}$ & Variation in horizontal fluid velocity & $\mathrm{m} \mathrm{s}^{-1}$ \\
\hline$W$ & Particle settling velocity & $\mathrm{m} \mathrm{s}^{-1}$ \\
\hline$w^{\prime}$ & Variation in vertical fluid velocity & $\mathrm{m} \mathrm{s}^{-1}$ \\
\hline$Z, z$ & Height above bottom of flume channel & $\mathrm{m}$ \\
\hline$\alpha$ & Sticking efficiency & \\
\hline$\beta$ & Coagulation coefficient & $\mathrm{cm}^{3}$ cell $^{-1} \mathrm{~s}^{-1}$ \\
\hline$\Delta \rho$ & $\begin{array}{l}\text { Excess density of cells compared to } \\
\text { seawater }\end{array}$ & $\mathrm{g} \mathrm{cm}^{-3}$ \\
\hline$\varepsilon$ & Mechanical turbulent kinetic energy & $\mathrm{m}^{2} \mathrm{~s}^{-3}$ \\
\hline$\gamma$ & Fluid shear rate & $\mathrm{s}^{-1}$ \\
\hline$\mu$ & Cell growth rate & $d^{-1}$ \\
\hline$v$ & Kinematic viscosity & $\mathrm{m}^{2} \mathrm{~s}^{-1}$ \\
\hline
\end{tabular}

ESD of $22 \mu \mathrm{m}$. However, because of their fractal nature, the ESD of algal cell aggregates is expected to be somewhat larger than the predicted minimum value (Li \& Logan 1995). The maximum floc sizes enumerated by the Multisizer during the experiment had ESD values between 30 and $40 \mu \mathrm{m}$. Although these values correspond with the preliminary microscopy, the $100 \mu \mathrm{m}$ orifice used for particle size distribution (PSD) determination undoubtedly destroyed aggregates having an equivalent spherical diameter larger than 30 or $40 \mu \mathrm{m}$. As a result, our data may slightly underestimate the flocculation of algal cells in the flume.

The number of individual cells within aggregates was determined by employing a method similar to Gotschalk \& Alldredge (1989). Where aggregates were defined as particles having an ESD $>$ twice that of an individual cell $(2 \times 3.5 \mu \mathrm{m})$, the samples were agitated to break apart any aggregates and the particle size distribution was subsequently measured using the Coulter Multisizer. The disaggregated cell counts were used to estimate (1) the specific growth rate of the culture, and (2) the number of cells bound within aggregates within the culture. The numbers of individual cells, having an $\mathrm{ESD} \approx 3.5 \mu \mathrm{m}$, from both the agitated and raw samples were compared. An increase in the number of individual cells following agitation is proportional to the number of aggregate bound cells in the raw sample.

Phytoplankton physiology. Photosynthetic efficiency of electron transport in Photosystem II $\left(F_{\mathrm{v}} / F_{\mathrm{m}}\right)$ was determined by using a fluorescence induction and relaxation (FIRe) fluorometer (Gorbunov \& Falkowski 2004) as an indication of the physiological health of a phytoplankton population (Kolber \& Falkowski 1993). Cells were also harvested from the second experiment, for caspase activity and superoxide dismutase (SOD) expression analyses, by means of centrifugation $\left(10000 \times g, 4^{\circ} \mathrm{C}, 10 \mathrm{~min}\right)$ and immediately frozen in liquid nitrogen and stored at $-80^{\circ} \mathrm{C}$ until processing.

Caspase activity. Cells were resuspended in caspase activity buffer: $50 \mathrm{mM}$ N-Cyclohexyl-2-aminoethanesulfonic acid ( $\mathrm{pH} 7.3), 100 \mathrm{mM} \mathrm{NaCl}, 10 \%$ sucrose, $0.1 \%$ 3-[(3-Cholamidopropyl)dimethylammonio]propanesulfonic acid, $10 \mathrm{mM}$ dithiothreitol. Cells were sonicated, and cellular debris was pelleted by means of centrifugation $\left(16000 \times g, 4^{\circ} \mathrm{C}, 2 \mathrm{~min}\right)$ as described in Bidle et al. (2007). Cell extracts were incubated with $50 \mu \mathrm{M}$ IETD-7-Amino-4-trifluoromethyl coumarin (Calbiochem, San Diego, CA) for $4 \mathrm{~h}$ at $25^{\circ} \mathrm{C}$. Fluorescence was measured by using a Spectra Max Gemini XS plate reader (excitation wavelength $=400 \mathrm{~nm}$, emission wavelength $=505 \mathrm{~nm}$ ).

Superoxide dismutase expression. Sample protein concentration was quantified using the bicinchoninic acid method (kit made by Pierce Biotechnology) where $5 \mu \mathrm{g}$ of sample were loaded on a $15 \%$ sodium dodecyl sulfate polyacrylamide electrophoresis (SDS/PAGE) gel and then transferred onto a polyvinylidene fluoride (PVDF) membrane. The blots were then probed with anti-TpMnSOD (1:1000), raised against the recombinant MnSOD from Thalassiosira pseudonana (WolfeSimon et al. 2006). Horseradish peroxidase (HRP) conjugated to a polyclonal goat anti-rabbit IgG (Pierce; 1:30 000) was used, followed by chemoluminescence detection (SuperSignal; Pierce).

Transparent exopolymer particle abundance. Relative changes in transparent exopolymer particles (TEP) were enumerated in triplicate following the spectro photometric alcian blue staining technique of Passow \& Alldredge (1995a). However, rather than calibrate the concentration of TEP to a Xanthan gum standard curve, relative changes in the TEP abundance were monitored by normalizing all values of TEP to the lowest (and first) measured value (Day 9). These qualitative estimates were used to assess changes in the levels of TEP.

Bacterial abundance. From each sample of the second mesocosm experiment, $15 \mathrm{ml}$ were fixed with a final concentration of $0.2 \%$ formalin. Bacterial abundance was determined using a DNA-specific stain, 4, 6diamindino-2-phenylindole (DAPI). With minor modifications (we used black filters instead of staining) we followed the DAPI staining technique as described in Porter \& Feig (1980). The DAPI stained and mounted samples were stored at $-4^{\circ} \mathrm{C}$ for less than $2 \mathrm{wk}$ prior to 
enumeration. Imaging of the fixed sample slides was conducted using an Olympus BX60 light microscope at $100 \times$ magnification. An Olympus America camera controlled by Olympus MicroSuite software was mounted to the microscope to allow for the capture of 5 randomly located digital images from each stained slide. Each image was sub-divided into 100 equally-sized squares and a contiguous 5 square $\times 5$ square grid was randomly assigned within the image. Individual bacteria within the 5 square $\times 5$ square grid were subsequently counted. In both the random field selection and grid counting, a random number generator was used to provide the coordinates of the field to be imaged or the grid to be counted. We used the freely available image analysis software ImageJ (US National Institute of Health) for bacterial cell enumeration. The counts from each of the 5 grids were used to extrapolate the bacterial abundance for each triplicate sample.

Sticking efficiency. Particle sticking efficiency, $\alpha$, is the ratio of successfully adhesive particle collisions to the total number of particle collisions that result from physically mediated interactions. The sticking efficiency of a system is manifest through time-dependent variations in the measured particle concentrations. The observed rate of coagulation can be compared to theoretical models of physically based coagulation processes to estimate the mean sticking efficiency in the natural system. While this method of estimating sticking efficiency has been successfully tested for clay particles (Hunt 1982) and colloids (Brunk et al. 1998), it has yet to be tested for systems containing algal cells.

In a system containing only algal cells, the particle size distribution changes as a result of cell growth $\left(\mu\right.$, time $\left.{ }^{-1}\right)$, gravitational settling, and coagulation $(\beta$, time $^{-1}$ ) (Jackson 1990). This is illustrated by a simplified formulation of Jackson's (1990) algal cell aggregation model:

$$
\frac{\mathrm{d} C}{\mathrm{~d} t}=\mu C-\frac{W}{Z} C+\alpha \beta C
$$

where $C$ is the volume concentration of cells (cells volume $^{-1}$ ), $t$ is time, $W$ is the settling velocity (length time $\left.^{-1}\right), Z$ is the distance a settling particle must fall to be removed from or enter into the open system, and $\beta C$ is a synthesis term of the coagulation processes (cells volume $^{-1}$ time $^{-1}$ ) described in detail in Jackson (1990).

If biomass gains (cell growth) into, and losses (cell settling) from an algal cell size distribution are taken into account, changes in the particle size distribution will reflect the rate of coagulation of algal cells:

$$
\frac{\mathrm{d} C}{\mathrm{~d} t}-\mu C+\frac{W}{Z} C=\alpha \beta C
$$

While direct measurement of algal cell coagulation is difficult, sticking efficiency can still be estimated if a suitable model of coagulation processes $\left(\beta_{\mathrm{m}} C\right)$ is applied (where $\beta_{m} C=\beta C$ ) and Eq. (2) is re-arranged:

$$
\alpha=\frac{\frac{\mathrm{d} C}{\mathrm{~d} t}-\mu C+\frac{W}{Z} C}{\beta_{m} C}
$$

The 3 terms in the numerator of Eq. (3) can be measured or calculated from first principles. At the $20 \mathrm{~cm}$ depth in the flume, cell volume concentration $\left[\mathrm{d} C(\mathrm{~d} t)^{-1}\right]$ and growth $(\mu C)$ were directly measured. Using a simple model of Stoke's settling velocity, and volume balance over time between each of the 3 collection depths $(40,20$, and $2 \mathrm{~cm}$ ), we were able to calculate the net effects of gravitational settling $\left[W C(Z)^{-1}\right]$ at the middle $(20 \mathrm{~cm})$ of our 3 collection depths within the flume. We assumed that the density of the Thalassiosira pseudonana cells was constant and that they were $0.0288 \mathrm{~g} \mathrm{~cm}^{-3}$ more dense $(\Delta \rho)$ than seawater (Waite $\&$ Nodder 2001).

To maintain a volume balance, we had to assume particle concentration was both horizontally homogenous and had a linear vertical gradient between our 3 discrete collection depths. However, based on the phytoplankton diffusion calculations of Prieto et al. (2002), when measured on time scales less than several days, the water column in our annular flume was nearly homogenous. As a result, measurements of mass balance at shorter time intervals, especially during the initiation and maintenance phases, were unreliable because there was not significant time for algal cells to settle between the points of the sampling grid. Consequently the model was initiated with data taken from samples collected about 6 to $7 \mathrm{~d}$ apart.

The denominator of Eq. (3) was calculated by using the Coulter Counter to measure the particle distribution at $20 \mathrm{~cm}$ depth. This continuous particle size distribution was then sectionalized, or binned into 10 discrete size-volume classes (Gelbard et al. 1980). The upper limit of each bin was twice the lower limit. Next, the sectionalized volume concentration was used to initiate the coagulation model of Jackson \& Lochmann (1992) such that the modeled rate of coagulation is represented by:

$\beta_{m} C=\frac{1}{2} \sum_{i=1}^{l-1} \sum_{j=1}^{l-1} \beta_{i, j, l} Q_{i} Q_{j}-Q_{l} \sum_{i=1}^{l-1} \beta_{i, l} Q_{i}-\frac{1}{2} \beta_{l, l} Q_{l}^{2}-Q_{1} \sum_{i=l+1}^{s} \beta_{i, l} Q_{i}$

Here, the right hand side of Eq. (4) retains the nomenclature of Jackson \& Lochmann (1992), where $i, j$, and $l$ are indices of the sectionalized particle size distribution, $Q_{i}, Q_{j}$, and $Q_{l}$ are the total volume of sections $i_{1} j_{\text {, }}$ and $l_{1} s$ is the number of sections, and $\beta_{i, j, l}, \beta_{i, l}$ and $\beta_{l, l}$ are coagulation coefficients that describe the interactions between particles in the sectionalized size distribution. Each coagulation coefficient represents the sum of all particle interactions resulting from Brownian motion $\left(\beta_{\mathrm{B}}\right)$, differential settling $\left(\beta_{\mathrm{D}}\right)$ and shear $\left(\beta_{\mathrm{S}}\right)$ 
(McCave 1984). Brownian motion collisions are a result of the sub-microscale random motions of particles, also known as perikinetic interactions, while differential settling and fluid shear are orthokinetic interactions whereby particles collide as a result of hydrodynamics and differences between their relative velocities. We assumed that coagulation due to Brownian motion was not a significant mechanism of particle interaction $\left(\beta_{\mathrm{B}}=0\right)$, which was reasonable, as evidence of Brownian pumping was not evident in the PSD measured in the flume. As a result, we only considered coagulation due to orthokinetic interactions $\left(\beta_{\mathrm{D}}\right.$ and $\left.\beta_{\mathrm{S}}\right)$ in our estimate of algal cell sticking efficiency.

Substituting Eq. (4) into Eq. (3), and formally expressing the numerator to reflect the sectionalized approach (where $m$ is biomass volume), Eq. (5) shows the form of Eq. (3) implemented to estimate the sticking efficiency of the Thalassiosira pseudonana flume experiments.

$$
\alpha=\frac{\frac{\mathrm{d} Q_{1}}{\mathrm{~d} t}-\mu_{l} Q_{l}+Q_{1} Z^{-1} \int_{m l-1}^{m l} w(m) \mathrm{d} m}{\frac{1}{2} \sum_{i=1}^{l-1} \sum_{j=1}^{l-1} \beta_{i, j, l} Q_{i} Q_{j}-Q_{l} \sum_{i=1}^{l-1} \beta_{i, l} Q_{i}-\frac{1}{2} \beta_{l, l} Q_{l}^{2}-Q_{l} \sum_{i=l+1}^{S} \beta_{i_{1} l} Q_{l}}
$$

To model algal cell coagulation in the flume, we used the sectionalized particle size distribution and fluid shear $\left(\gamma=0.09 \mathrm{~s}^{-1}\right)$ measured in the flume. Because there is less than a $20 \%$ difference between the length of the major and minor axes, Thalassiosira pseudonana cells are approximately spherical and can be used as a model organism for particle interaction studies. A fractal coagulation kernel having a fractal dimension of 2.33 (Jackson et al. 1997) was used for all higher order (where $l>1$ ) particle interactions. Otherwise, individual $T$. pseudonana cells $(l=1)$ were defined as having a curvilinear collision function. Cell division in size classes larger than that of individual phytoplankton was likely insignificant (for $1>1, \mu=0$ ), due to the short duration of this experiment and the relatively short distance an aggregate needed to settle out of the mass balance measurement grid. Furthermore, significant coagulation of algal cells occurred during the maintenance and senescence phases, periods when cell division rates were low. As a result, all size classes except for the smallest class (containing individual cells) excluded phytoplankton division. Algal cell division, as determined experimentally, was assumed to only occur in Size-class 1, which contained individual T. pseudonana cells. Gravitational settling, the third term within the numerator (Eq. 5), was assumed to occur only in the size classes larger than the size class used for the growth term. In this study, the distribution of volume concentration was simplified into 10 size classes. While Sizeclass 1 contained individual cells, Size-classes 2 to 10 contained all other measured algal particles.
Data analysis. The standard deviation, calculated as the square root of the mean squared deviations about the mean, was determined for the following parameters: phytoplankton abundance, fraction of cells aggregated, photosynthetic efficiency, caspase activity, relative TEP abundance, bacterial abundance, and sticking efficiency. Where a parameter was not replicated, such as sticking efficiency during the maintenance phase of the mesocosm, the standard deviation could not be determined. Simple linear regression and a 2 -tailed $t$-test were used to determine the variability and the significance of bacteria and TEP in the formation of phytoplankton aggregates in the mesocosm.

\section{RESULTS}

Although 2 separate mesocosm experiments were used to replicate our sticking efficiency analysis, extensive physiological parameters were only collected during the second experiment and are reported in this study. As described in the 'Materials and methods' section, there are 2 mechanisms of algal particle interaction in the annular flume; differential sedimentation and fluid shear. A cross-section of the fluid shear rate within the annular flume is shown in Fig. 2A. The spatially averaged shear rate of the flume cross-section is $0.05 \mathrm{~s}^{-1}$. However, there are 2 primary regions of increased rates of fluid shear; the bottom and the top of the flume channel. Along both the top and the bottom of the flume, the highest rates of shear are found at the intersection with the side walls. The maximum shear rate, $1.6 \mathrm{~s}^{-1}$, was measured at the top of the LDV sample grid-near the counter-rotating top of the flume. This is the region of maximum shear generation within the flume. The highest shear rate measured at the bottom of the LDV sampling grid, near the bottom of the flume, was $0.29 \mathrm{~s}^{-1}$. Along the bottom of the flume, the region of increased shear $\left(>0.1 \mathrm{~s}^{-1}\right)$ did not extend more than 1.5 to $2 \mathrm{~cm}$ above the flume bottom. Our lowest sampling location (Fig. 2A, at $1.5 \mathrm{~cm}$ above the flume bottom) within the flume occurred within the upper reaches of this region of increased shear. In the middle of the flume channel, the minimum shear rate measured was $0.002 \mathrm{~s}^{-1}$. Assuming that the fluid shear rates of the unmeasured areas (white portions near the edges of the cross-section in Fig. 2) of the flume were greater than $0.1 \mathrm{~s}^{-1}, 89.3 \%$ of the flume cross-sectional area had a fluid shear rate less than $0.1 \mathrm{~s}^{-1}$. Shear rate within the annular flume is much lower than the rates of fluid shear used in previously published studies (Fig. 1, Table 1) of phytoplankton sticking efficiency. The overall low rate of fluid shear within the annular flume allowed coagulation processes to occur both at low energy levels and with minimal physical disruption to the aggregates. 
As the number of sinking aggregates increased, there was an uneven distribution of settled material at the bottom of the flume. The direction of the flow field vectors, near the bottom of the flume (Fig. 2A), corresponds with the observed increase in accumulation of material towards the outer wall of the flume bottom (Fig. 3F). The mean magnitude of the cross-channel flow field vectors is $7.6 \times 10^{-4} \mathrm{~m} \mathrm{~s}^{-1}$ and is 3 orders of magnitude smaller than the mean along-channel horizontal velocity, $0.13 \mathrm{~m} \mathrm{~s}^{-1}$. Consequently, the mean along-channel velocity of the flume was used as the characteristic velocity value $\left(u=0.13 \mathrm{~m} \mathrm{~s}^{-1}\right)$ to estimate the Reynolds number of the fluid environment surrounding an individual phytoplankton cell in the experiment $\left(\operatorname{Re}=u l v^{-1}\right)$. While the kinematic viscosity (v) was approximated as $1 \times 10^{-6} \mathrm{~m}^{2} \mathrm{~s}^{-1}$, the characteristic length scale of Thalassiosira pseudonana is the mean ESD $\left(L \sim 4 \times 10^{-6} \mathrm{~m}\right)$. The resultant Reynolds number, 0.50 , indicates that the low energy environment of the flume is dominated by viscous forces and that the flow is nearly laminar.

The spatially weighted mean TKE dissipation rate of the flume was $8.8 \times 10^{-7} \mathrm{~m}^{2} \mathrm{~s}^{-3}$. A TKE dissipation rate of this magnitude is comparable to the top $20 \mathrm{~m}$ of the ocean's surface on a calm day (Petersen et al. 1998). Fig. 2B, a cross-section of TKE dissipation rate within the flume, shows the maximum $\left(\varepsilon=1.36 \times 10^{-5} \mathrm{~m}^{2} \mathrm{~s}^{-3}\right)$ at the top of the water column (near the counterrotating top) near the outer wall of the flume. Otherwise, $78 \%$ of the flume had TKE dissipation rate values with an order of magnitude equal to or less than $10^{-7} \mathrm{~m}^{2} \mathrm{~s}^{-3}$.
As the number of cells and aggregates within the flume changed over the duration of the $23 \mathrm{~d}$ experiment, the various stages of bloom development and collapse were evident (Fig. 3). The concentration of Thalassiosira pseudonana cells increased between Days 0 to 6 (Fig. 4A) through exponential growth and into the early part of the stationary phase. After remaining in stationary phase for about $1 \mathrm{wk}$, the phytoplankton bloom transitioned from the late stationary (Day 15) to the senescence phase (Day 23). During the decline of the bloom (Days 15 to 23), there was a noticeable accumulation of algal cell material on the bottom of the flume channel (Fig. 3E,F). The accumulated material on the bottom of the flume was distinctly separate from the water column. A nepheloidlike layer was not observed between the accumulated material at the bottom of the flume and the remainder of the water column. Coupling this observation with the shear cross-sections of Fig. 2 indicates that resuspension of algal cells from the bottom of the flume was undetectable and was unlikely to have occurred. Furthermore, if re-suspension of previously sedimented algal material had occurred to a significant degree, its effects would have been measured in the samples collected from $2 \mathrm{~cm}$ above the bottom of the flume. The replicate samples of cell concentrations for each of the 3 collection depths $(40,20$, and $2 \mathrm{~cm}$, respectively) were consistent. Comparing each of the sample depths, the standard deviations did not vary from one another by more than $5 \%$ (data not shown).

During the initiation phase (Days 1 to 6 ), photosynthetic efficiency of Photosystem II, as measured by
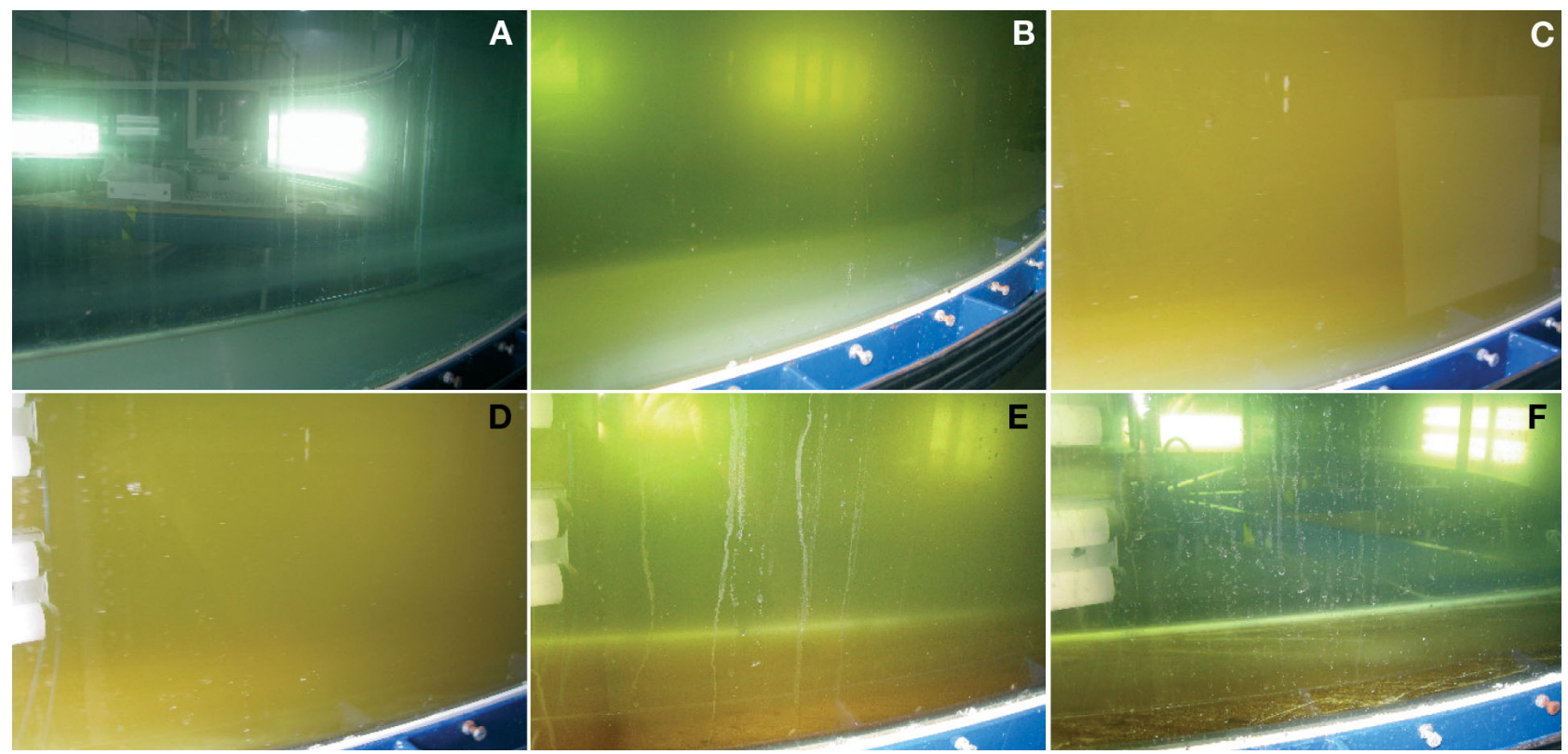

Fig. 3. Thalassiosira pseudonana. Time lapse images of a T. pseudonana bloom in the annular flume. (A,B) Initiation, and (C,D) maintenance phases. (E,F) Settling of $T$. pseudonana cells during the transition from bloom maintenance to senescence 

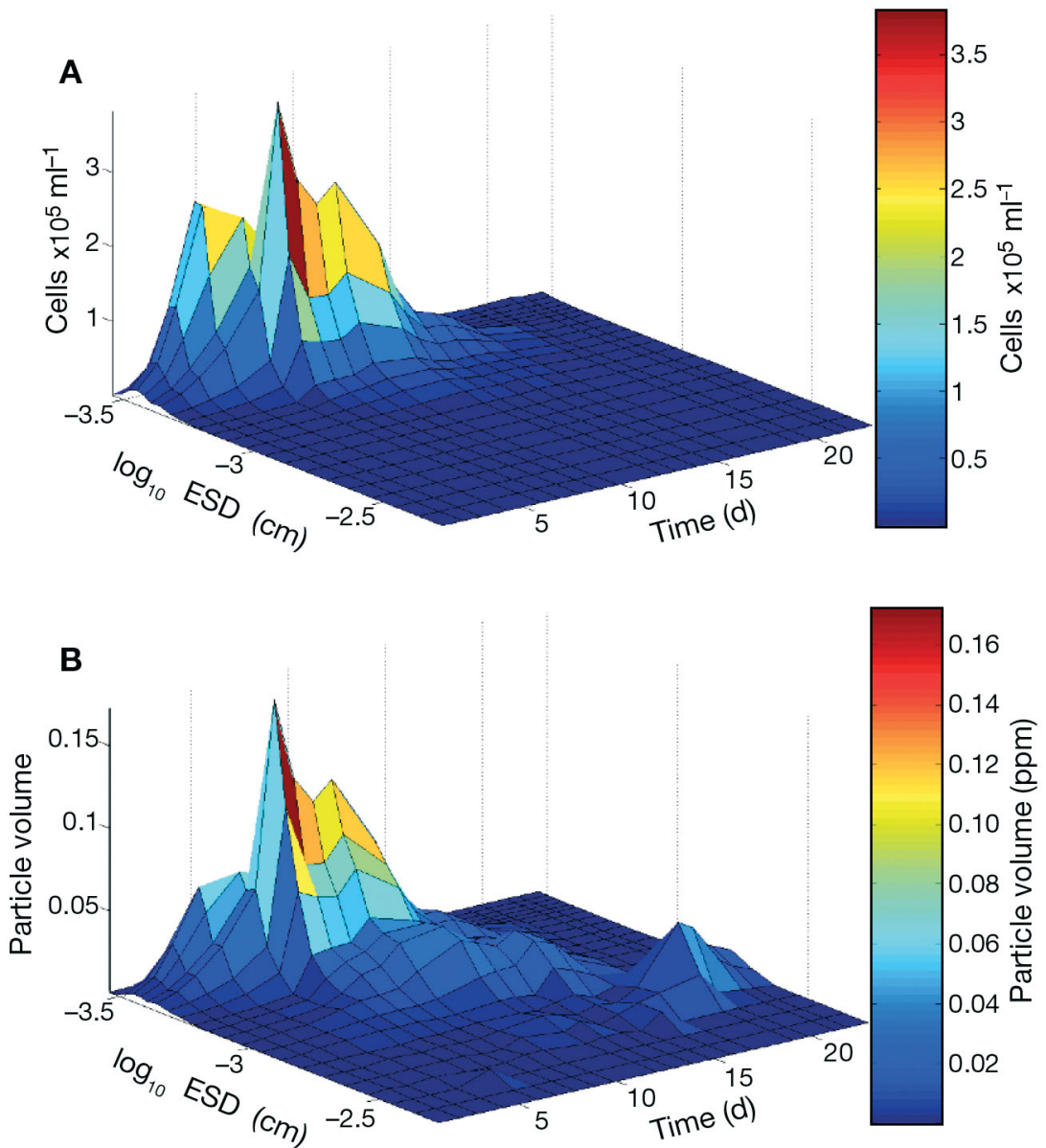

Fig. 4. Thalassiosira pseudonana. Particle size evolution during a T. pseudonana mesocosm experiment. (A) Cell concentration, (B) volume fraction of water occupied by cells. ESD: equivalent spherical diameter variable fluorescence $\left(F_{\mathrm{v}} / F_{\mathrm{m}}\right)$, increased from below the level of detection to between 0.5 and 0.6 (see Fig. 6). Following a decline in the photosynthetic efficiency, the phytoplankton cell concentration stopped increasing and stabilized near Day 5. During the stationary, or maintenance, phase of the bloom, phytoplankton cell division (or growth rate) slowed, yet the cells did not immediately settle out from the water column. The maintenance phase of the bloom was characterized by the decrease of both photosynthetic efficiency and cell concentration over time.

The transition from the maintenance to the senescence phase occurred between Days 10 and 20-when there was a concomitant decline in the slopes of cell concentration (Fig. 5) and photosynthetic efficiency (Fig. 6). The senescence phase of the bloom did not dominate the mesocosm until after Day 20 when the photosynthetic efficiency rapidly fell from about 0.14 to near zero. Because our calculations require discrete time steps, we defined the end of the maintenance phase as occurring at the mid point of the steady decline in cell concentration, approximately Days 15 to 16 . The senescence phase of the bloom lasted from Day 16 until the photosynthetic efficiency approached

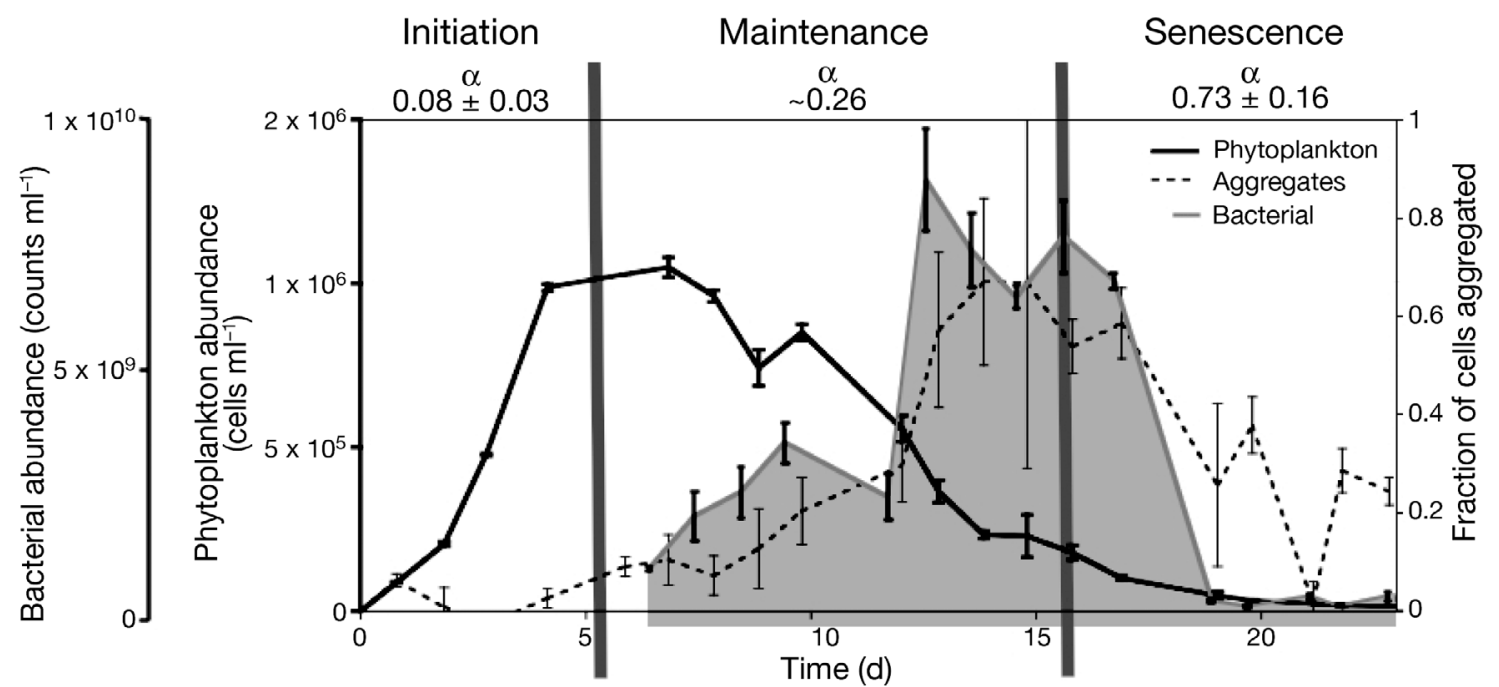

Fig. 5. Sticking efficiency $(\alpha \pm \mathrm{SD})$ of the mesocosm was measured during the 3 physiologically defined bloom phases: initiation, maintenance, senescence. The cell concentration and subsequently calculated aggregated cell fraction were tracked throughout the mesocosm experiment. Enumeration of bacteria (grey shaded area) within the mesocosm was not started until the maintenance phase 

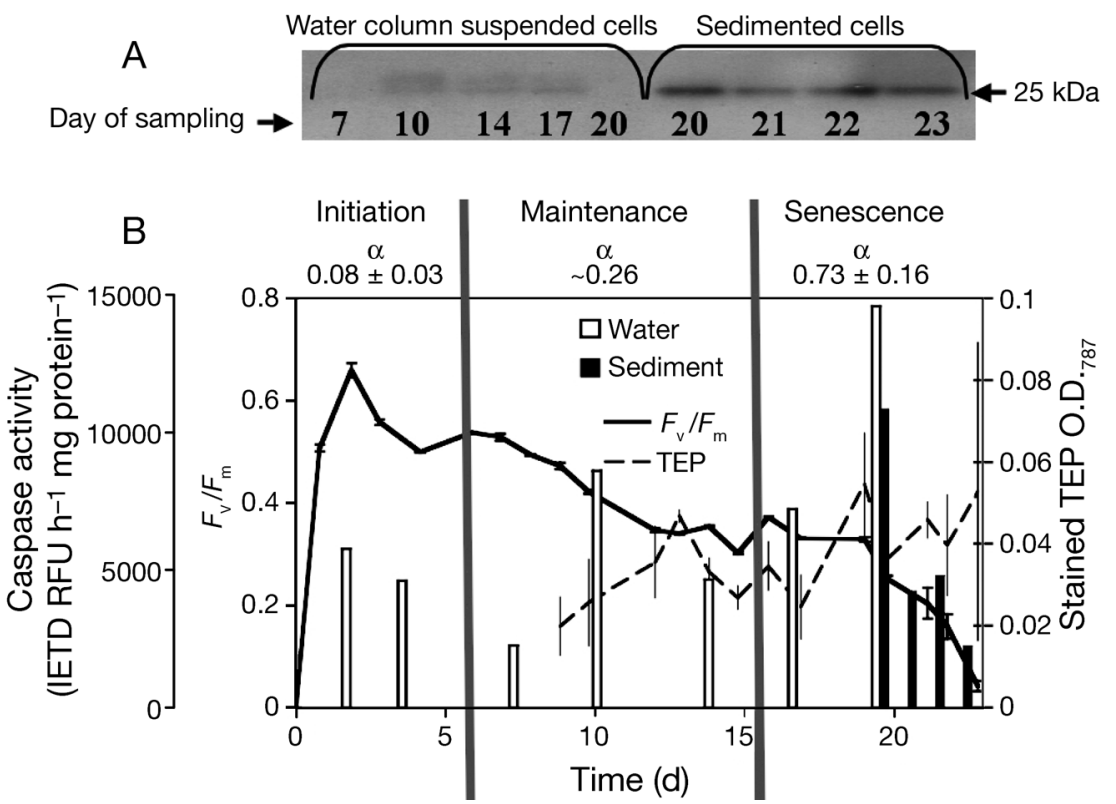

Fig. 6. (A) Western blot of SOD protein (band at $25 \mathrm{kDa}$ ) expression for the both water column suspended and sedimented diatom cells, and (B) sticking efficiency $(\alpha \pm \mathrm{SD})$ of each bloom phase is aligned with caspase activity (for both the water column suspended and sedimented diatom cells), photosynthetic efficiency $\left(F_{\mathrm{v}} / F_{\mathrm{m}}\right.$ of water column suspended cells), and relative spectrophotometric TEP staining (water column only)

zero on Day 23. The decline of the bloom during the senescence phase was distinctly visible in the flume from Days 17 to 23 (Fig. 5).

Another indicator of cell physiology, oxidative stress (as indicated by SOD expression), increased prior to the crash of the bloom (Fig. 6). Oxidative stress was most visible in the algal cells accumulated on the bottom of the flume but was not observed in cells that remained suspended in the water column as the bloom transition from early to mid-senescence took place around Day 20. Concurrent with the changes in cellular oxidative stress, there was also an increase in the activity of enzymes responsible for the initiation of apoptotic pathways. Caspase-8 activity, normalized to protein concentration, increased through the senescence phase (Fig. 6). The peak in Caspase-8 activity coincided with the largest increase in TEP between 2 sample points. Overall, there was also a slight increase in the relative concentration of TEP as the bloom aged (Fig. 6).

Both cell concentration and cell volume fraction (the fraction of a volume of water that was occupied by algal particles) measurements were used as an indicator of physical changes within the phytoplankton bloom. Cell volume fraction will approximate cell concentration, but will deviate if aggregation occurs such as was observed during the senescence phase (Fig. 4). The deviation between volume fraction and cell concentration results from the fractal nature of phyto- plankton aggregation (Li \& Logan 1995). An increase in the mean particle volume may particularly be attributed to aggregation when large increases in mean particle volume occur while photosynthetic efficiency of the phytoplankton is decreasing during the senescence phase of the bloom. For example, during the initiation phase of the experiment, mean particle volume remained stable at about $31 \mu^{3}$ (data not shown) while photosynthetic efficiency was highest during bloom initiation. A volume of $31 \mu^{3}$ approximates an individual Thalassiosira pseudonana cell of $3.9 \mu \mathrm{m}$ ESD. This is slightly larger than the measured mode ESD of $3.5 \mu \mathrm{m}$ because rapidly dividing algal cells skew the volume concentration distribution due to their slight increase in volume prior to cellular division. Throughout the maintenance phase both the cell concentration and the cell volume fraction (Fig. 4) along with photosynthetic efficiency (Fig. 6) steadily declined. Yet, during the maintenance phase, there was not a visibly discernible change of the bloom within the annular flume (Fig. 3C,D). However, as the T. pseudonana cells entered the senescence phase near Days 15 to 17 , changes in both the particle size distribution (Fig. 4) and in the optical clarity of the bloom (Fig. 3D,E) were apparent. Additionally, algal cell aggregation became apparent as the mean particle volume increased until Days 21 to 22 to an ESD of $9 \mu \mathrm{m}$.

In addition to measuring the mean particle number and volume fraction, we estimated the number of aggregated phytoplankton as a fraction of the total bloom population. The fraction of aggregated phytoplankton cells was highest during the transition from the end of the maintenance phase through the beginning of the senescence phase (Fig. 5). There was a notable decrease in the fraction of aggregated cells on approximately the same day as the largest mean particle volume. This would suggest that while many aggregates settled out of the water column between Days 20 and 22, the number of suspended (and subsequently measured) individual cells remained relatively stable. Supporting this interpretation is the apparent growth rate of Thalassiosira pseudonana. The apparent growth rate is the balance between an increase in biomass due to cell division and the loss of biomass due to the settling of individual cells. In the framework of our experiment and analysis, the loss of algal biomass 
due to settling is partitioned into 2 terms - individual algal cells (biomass losses from Size-class 1) and aggregates (biomass losses from Size-classes 2 to 10). Where the apparent growth rate is positive, such as in the initiation phase, individual cells are dividing more rapidly than they are settling out of the water column. Conversely, during the end of the maintenance phase and into the senescence phase of the bloom, the apparent growth rate decreases and ultimately becomes negative as individual algal cells settle downward either as individuals or as they are scavenged from the water column by larger particles.

Increased bacterial abundance and hydrolytic enzyme activity has also been observed with phytoplankton aggregation (Smith et al. 1992). Indeed, during our experiment, total bacterial counts were highest during the end of the maintenance and the beginning of the senescence phase, when phytoplankton aggregates were prevalent in the flume (Fig. 5). The peak in bacterial population coincided with the time period having the largest fraction of aggregated Thalassiosira pseudonana cells.

After determining the growth rate and settling velocities, as described in 'Materials and methods', the sticking efficiency for each phase of the Thalassiosira pseudonana bloom was estimated (Figs. 5 \& 6) by applying Eq. (5) to the initiation and senescence phases of both of the mesocosm experiments and to the maintenance phase of only the second experiment (due to sampling error, data were collected at only 1 depth during the maintenance phase of the first experiment). As a result, the initiation, maintenance, and senescence phases of the T. pseudonana bloom had respective sticking efficiencies of $0.08 \pm 0.03,0.26$, and $0.73 \pm 0.16$ (Fig. 5)

\section{DISCUSSION}

Measurements of particle aggregation dynamics at low shear are critically important because they reflect the conditions under which fragile marine snow is formed in nature. Phytoplankton blooms occur as nutrient-replete water columns stratify and the mixed layer depth shallows, allowing algal cells to remain in the euphotic zone. As the phytoplankton bloom matures, nutrients in the upper mixed layer are depleted and the phytoplankton population begins to senesce. During these latter stages of the bloom, marine snow becomes evident. Accordingly, aggregates are formed when cell concentrations are high and rates of shear are low. Our laboratory manipulations mimic this sequence of events and provide a physiological basis for such bloom dynamics.

\section{Algal cell physiology and sticking efficiency}

Significant changes in Thalassiosira pseudonana physiology occurred in concert with an increase in the sticking efficiency of the cells. The goal of this study was to examine particle interactions and the concordant changes in cell physiology in a low shear environment more characteristic of natural bloom conditions. During our low-shear mesocosm bloom, we observed an increase in the sticking efficiency of algal cells as the population aged and began to senesce. The increase in the sticking efficiency was mirrored by declines in the photosynthetic efficiency, which explained $66 \%$ of the variation in the fraction of aggregated cells. As evidenced by the slow decline of the photosynthetic efficiency of Photosystem II without a concomitant decline in irradiance, during the maintenance phase the diatom bloom in this mesocosm began its demise into senescence due to a slow draw down of inorganic nutrients.

Plants and algae generate reactive oxygen species (ROS) as metabolic byproducts of the electron transport during respiration and photosynthesis. Under adverse environmental conditions an increase in ROS production leads to the induction of various antioxidant enzymes, such as superoxide dismutase (SOD), catalase, and ascorbate peroxidase, to detoxify harmful damage to lipids, thiol proteins and nucleic acids (Butow et al. 1997). Induction of a biochemical cascade leading to cell death occurs once ROS production exceeds the antioxidant cellular capacity. Previous studies have shown a similar mechanism in the demise of the dinoflagellate Peridinium gatunense bloom which was initiated by $\mathrm{CO}_{2}$ limitation that led to the accumulation of ROS (Vardi et al. 1999). The rise in antioxidant enzymatic activities and in the fraction of ROS-positive cells towards the peak of the bloom corroborate this observation. Additionally, induction of oxidative stress played a central role in triggering a coordinated cell death of the entire $P$. gatunense population (Vardi et al. 2007).

Autocatalytic programmed cell death (PCD) has recently been demonstrated in major classes of phytoplankton in response to environmental stresses, such as nutrient and light deprivation, UV, allelochemicals and viral infection (Bidle \& Falkowski 2004). This selfdestructive cellular mechanism was proposed to play a critical role in the demise of a phytoplankton bloom independent of zooplankton grazing. A specific family of cysteine aspartate-specific proteases (caspases) constitutes an ubiquitous biochemical hallmark of triggering the execution phase of the PCD pathway in metazoans (Riedl \& Shi 2004). Recently, caspase activities have also been implicated as part of phytoplankton cell death machinery activated in response to nutrient 
depletion and virus infection (Segovia et al. 2003, Berman-Frank et al. 2004).

Diatoms appear to rely primarily on a chloroplast localized MnSOD to scavenge superoxide to molecular oxygen and hydrogen peroxide (Wolfe-Simon et al. 2006). Using an antibody raised against Thalassiosira pseudonana MnSOD (Wolfe-Simon et al. 2006), we observed the induction of MnSOD prior to bloom termination, indicating that cells experienced an oxidative stress. During this phase, cells exhibited impaired photosynthetic efficiency and elevated caspase activity. The high caspase activity was coupled with an increase in TEP production and a progressively increasing sticking efficiency.

Such an increase in sticking efficiency may result from a combination of 2 distinct, yet related, processes. One reason for the increasing sticking efficiency during this transition may be the stabilization of the cell's surface area, due to decreased cellular division, relative to the cell's photosynthetic efficiency. As described by Busch \& Stumm (1968); during exponential growth, cell surfaces may be synthesized faster than they can be covered by exuded polymers. When cell growth and division slows down while photosynthetic machinery are still efficient, the amount of the cell's surface that is covered by exuded photosynthate will increase. In our mesocosm, the rate of algal cell division stabilized as the bloom proceeded from bloom initiation into bloom maintenance while photosynthetic efficiency continued to steadily decline through bloom maintenance and into bloom senescence. Because the cells continued to photosynthesize without rapidly dividing or growing, excess photosynthate had the opportunity to accumulate without an increase in cell surface area. Another reason for increased sticking efficiency as the bloom progressed is the increase in cellular oxidative stress and the subsequent cellular response and TEP production that was observed during the maintenance and senescence phases. Similar to the Thalassiosira pseudonana cells of this study, Fe-stressed Trichodesmium spp. cultures and natural populations were recently shown to have induced caspase activity prior to increased production of TEP (Berman-Frank et al. 2007). This link between cells undergoing PCD and an increase in the pool of TEP was observed predominantly in sinking Trichodesmium cells, suggesting a higher proportion of vertical export of organic matter in PCD-high TEP-releasing cells. Although previous work has shown that TEP are abiotically formed from phytoplankton-released polysaccharides (Passow et al. 1994), until now there has been little quantitative evidence of a coupling of the cellular physiological status and TEP. Such a coupling of cellular physiology and TEP production, as shown in this study, may have important implications for the fate of organic matter produced during a phytoplankton bloom.

Accordingly, such an explanation requires TEP to act as the adhesive holding algal cells together upon collision. Indeed, both algal exudates (Myklestad 1974) and bacterial activity (Smith et al. 1995) tend to increase during the maintenance phase of a phytoplankton bloom. Although not mutually exclusive, the increase in the sticking efficiency may be a result of either algal cell exudates or an increase in 'background particles' such as TEP or bacteria. Background particles such as TEP (Engel 2000), or bacteria (Smith et al. 1995) have been demonstrated to play a crucial role in the sticking efficiency of algal cells (Hill 1992). If TEP serve as an adhesive during phytoplankton coagulation, then an increase in the number of aggregates will lag an increase in the concentration of TEP itself. When the aggregated fraction of cells could be reliably estimated (concentration $>10^{5}$ cells $\mathrm{ml}^{-1}$ ), significant variability between the number of aggregated cells and TEP was explained when aggregation lagged TEP by $1 \mathrm{~d}\left(\mathrm{n}=8, \mathrm{p}<0.001, \mathrm{r}^{2}=0.70\right)$. On the other hand, TEP concentration was not able to explain variation in the abundance of bacteria with $(\mathrm{n}=12, \mathrm{p}=$ $\left.0.003, \mathrm{r}^{2}=0.030\right)$ or without $\left(\mathrm{n}=12, \mathrm{p}=0.002, \mathrm{r}^{2}=\right.$ 0.013 ) a lag of $1 \mathrm{~d}$. However, bacterial abundance variability is explained by concomitant changes in the fraction of algal cells bound in aggregates $(n=8, p=0.001$, $\left.r^{2}=0.720\right)$. The strong correlation between TEP prior to aggregation supports the hypothesis of TEP acting as 'background particles' to increase the rate of algal cell aggregation. Meanwhile, bacteria appear to have colonized the aggregates in this mesocosm and may play a role in the strength of adhesion once an aggregate has been formed. Additionally, because turbulence is inversely proportional to bacterial production in the ocean (Moeseneder \& Herndl 1995), the role of bacteria on subsequent algal aggregate sticking efficiency may be enhanced under low shear conditions.

Despite the possible role of non-algal particles, our estimates of increasing sticking efficiency with the age of the bloom, which range from near 0 to about 0.73 , are comparable to previous studies (Table 1). Yet, given the general agreement between this study and previously published values of sticking efficiency, the maximum sizes of aggregates in the flume were much smaller than are observed under similar oceanic conditions. Under calm oceanic conditions, aggregation due to differential sedimentation is dominant compared to shear coagulation (Hunt 1980). For example, the level of energy in our experiment was comparable to the levels observed in the ocean by Riebesell $(1991,1992)$ and Kiørboe et al. (1998). However, the maximum size of algal cell aggregates in our flume were between 30 and $40 \mu \mathrm{m}$ (ESD) while the above cited field studies 
observed centimeter sized aggregates. The primary reason for this discrepancy in maximum observed particle size is that while oceanic particles have many meters over which differential sedimentation collisions may occur, the flume provided only $42 \mathrm{~cm}$ for differential sedimentation. The short settling path length of the flume prevented the formation, due to differential sedimentation, of larger aggregates.

As the mesocosm bloom progressed, differential sedimentation played an increasingly important part in the coagulation of algal cells. Following Hunt's (1980) simplifications, and assuming that Thalassiosira pseudonana cells (mean ESD $=3.5 \mu \mathrm{m}$ ) in our flume interacted with the mean algal particle size during each of the 3 phases of the bloom (mean ESD during: initiation = $3.5 \mu \mathrm{m}$, maintenance $=4.3 \mu \mathrm{m}$, senescence $=6.5 \mu \mathrm{m}$ ) the magnitude of the collision kernels was calculated (where $\gamma=0.05 \mathrm{~s}^{-1}$ and $\Delta \rho=0.028 \mathrm{~g} \mathrm{~cm}^{-3}$ ). Because the interacting particles during the initiation phase are very similar in size, coagulation due to differential sedimentation approached zero $\left(\beta_{\mathrm{D}}=0 \mathrm{~cm}^{3} \mathrm{~s}^{-1}\right)-$ allowing shear interactions $\left(\beta_{\mathrm{S}}=2.9 \times 10^{-18} \mathrm{~cm}^{3} \mathrm{~s}^{-1}\right)$ to dominate. While each of the 2 collision functions during the maintenance phase were nearly equal in influence $\left(\beta_{\mathrm{D}}=4.5 \times 10^{-18} \mathrm{~cm}^{3} \mathrm{~s}^{-1}, \beta_{\mathrm{S}}=3.9 \times 10^{-18} \mathrm{~cm}^{3} \mathrm{~s}^{-1}\right)$, differential sedimentation was the dominant mechanism of coagulation during the senescence phase $\left(\beta_{\mathrm{D}}=\right.$ $3.6 \times 10^{-17} \mathrm{~cm}^{3} \mathrm{~s}^{-1}, \beta_{\mathrm{S}}=8.3 \times 10^{-19} \mathrm{~cm}^{3} \mathrm{~s}^{-1}$ ). Similar to prediction and observations of the ocean, phytoplankton aggregation due to differential sedimentation dominated the late stages of this mesocosm bloom. While differential sedimentation plays an increasingly important role in aggregate formation during a phytoplankton bloom, changes in sticking efficiency will affect the overall rate of coagulation.

\section{Sticking efficiency and export flux}

In an overview of coagulation in marine systems, Jackson \& Lochmann (1993) analyzed an algal cell coagulation model with a 2 -stage variable sticking efficiency at low shear. They found that a 2-phase sticking efficiency model had the same timing and a slightly larger biomass export compared to a model with a constant sticking efficiency. However, when we applied a variable sticking efficiency $\left(\alpha_{I}=0, \alpha_{M}=0.25, \alpha_{S}=1\right.$; where I, M, and S represent the initiation, maintenance, and senescence phases, respectively) to each of the 3 phases (3 stage sticking efficiency) of a modified version of Jackson's (1990) coagulation model, both the timing and magnitude of the export event were different compared to the export modeled with a constant sticking efficiency (Fig. 7). A series of model blooms with both static $(\alpha=1)$ and the above-described
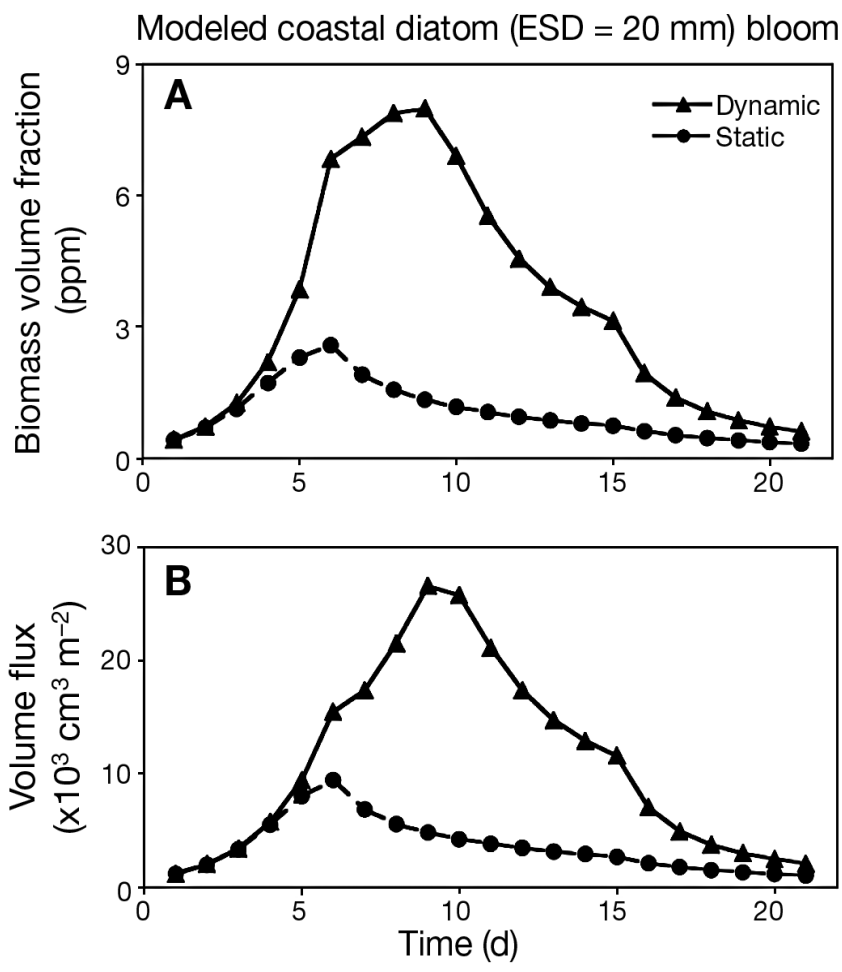

Fig. 7. (A) Volume fraction of the water occupied by phytoplankton, and (B) volume export flux for a dynamic $(\alpha=0$, $0.25,1 ; \mu=1.8,0.47,0)$ and a static $\left(\alpha=0.37\right.$ and $\left.\mu=0.40 \mathrm{~d}^{-1}\right)$ 1D particle aggregation model. Growth rate $(\mu)$ and sticking efficiency $(\alpha)$ were similar to our experimentally determined values from the annular flume. For each of the models, we used a rate of shear $\left(\gamma=0.1 \mathrm{~s}^{-1}\right)$ similar to the value measured in the annular flume

dynamic sticking efficiency were numerically simulated for the approximate length of the phytoplankton bloom observed in the mesocosm experiments. The duration of the initiation, maintenance, and senescence phases of the model runs were based on the observed lengths of each phase in the mesocosm experiments. One difference between the model and the experimental observations is the overall length of the bloom. In the numerical models, the export flux during the senescence phase stabilized by Day 21 for each simulated bloom. As a result, the numerical simulations were run for $21 \mathrm{~d}$ ( 1 model day $=1$ model time step) instead of the 23 observed in the mesocosms. The variable sticking efficiency increased the export flux by nearly a factor of 2 for all of the simulated oceanic conditions except for a less pronounced increase in export among large diatoms in a coastal simulation (Fig. 8).

When a phytoplankton bloom is initiated, a low sticking efficiency will allow biomass to increase such that cells reach a relatively high critical concentration $\left(C_{\mathrm{cr}}\right)$; the cell concentration at which biomass loss due to coagulation and settling is balanced by biomass 


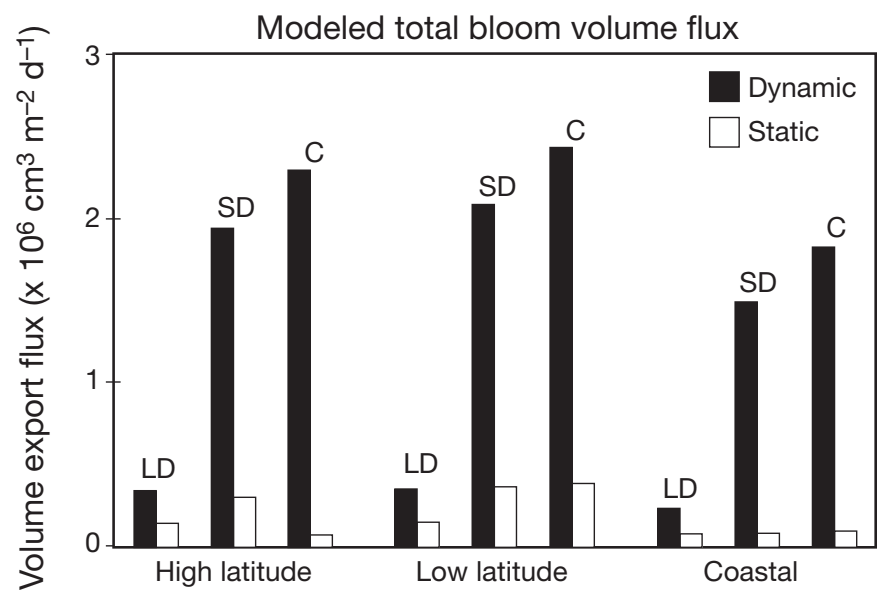

Fig. 8. Comparison of biomass export flux between static and dynamic sticking efficiency for 3 phytoplankton groups in different environments. In both the dynamic and static models, each type of phytoplankton had a size dependent growth rate that varied with the phase of the bloom (initiation, maintenance, senescence). LD: Large diatoms $\left(\mu=0.67 \mathrm{~d}^{-1}, 0.17 \mathrm{~d}^{-1}, 0 \mathrm{~d}^{-1}\right)$, SD: small diatoms $\left(\mu=1.8 \mathrm{~d}^{-1}, 0.47 \mathrm{~d}^{-1}, 0 \mathrm{~d}^{-1}\right), \mathrm{C}$ : coccolithophores $\left(\mu=1.8 \mathrm{~d}^{-1}, 0.47 \mathrm{~d}^{-1}, 0 \mathrm{~d}^{-1}\right)$. For all 3 phytoplankton groups in the dynamic model, sticking efficiency varied with bloom phase $(\alpha=0,0.25,1$, respectively). Physical conditions representative of typical ocean conditions were also tested such that high latitude $\left(\gamma=0.1 \mathrm{~s}^{-1}\right)$, low latitude $\left(\gamma=0.05 \mathrm{~s}^{-1}\right)$, and coastal $\left(\gamma=1 \mathrm{~s}^{-1}\right)$, phytoplankton blooms each had different rates of shear. Additionally, coccolithophore cells $\left(\Delta \rho=0.0355 \mathrm{~g} \mathrm{~cm}^{-3}\right)$ had a higher $\Delta \rho$ than diatom $\left(\Delta \rho=0.0288 \mathrm{~g} \mathrm{~cm}^{-3}\right.$, see 'Materials and methods') cells because coccolithophore ballast $\left(\mathrm{CaCO}_{3}\right)$ is approximately 1.23-fold more dense than diatom ballast (silica)

gains due to cellular division (Jackson 1990). In a phytoplankton bloom having 3 phases, the rate of coagulation rises as a result of the combination of a high concentration of cells and the gradually increasing sticking efficiency. The punctuated event illustrated in Fig. 7 indicates that aggregates rapidly formed as the cell number reached the critical cell concentration. Because sticking efficiency is difficult to parameterize, extremely small values $(\alpha<0.01)$ are likely to

Table 3. Predicted and measured critical $C_{\mathrm{cr}}$ and maximum $C_{\max }$ during the second mesocosm flume experiment using generally assumed values $(\alpha=1)$ of sticking efficiency and a comparison with mesocosm flume measurement-derived estimates of sticking efficency. See Table 2 for parameter definitions

\begin{tabular}{|lcclc|}
\hline Bloom phase & $C_{\mathrm{cr}}$ & $C_{\max }$ & $\mu^{\prime}$ & $\alpha$ \\
\hline Predicted & & & & \\
Initiation & $3.7 \times 10^{6}$ & $1 \times 10^{6}$ & 1.8 & 1 \\
Maintenance & $9.7 \times 10^{5}$ & $1 \times 10^{6}$ & 0.47 & 1 \\
Senescence & $2.0 \times 10^{4}$ & $1 \times 10^{5}$ & 0.01 & 1 \\
Measured & & & & \\
Initiation & $4.7 \times 10^{7}$ & $1 \times 10^{6}$ & 1.8 & 0.08 \\
Maintenance & $3.8 \times 10^{6}$ & $1 \times 10^{6}$ & 0.47 & 0.26 \\
Senescence & $2.8 \times 10^{4}$ & $1 \times 10^{5}$ & 0.01 & 0.73 \\
\hline
\end{tabular}

be unreliable. Because the maximum value is 1 , the sticking efficiency is capable of altering the critical concentration of a phytoplankton bloom by up to 2 orders of magnitude. With this relative insensitivity in mind, using $C_{\mathrm{cr}}=\mu^{\prime}\left(10.4 \alpha \gamma \mathrm{r}^{3}\right)^{-1}$ (Jackson \& Burd 1998), the $C_{\mathrm{cr}}$ during each of the bloom phases in this mesocosm was calculated (Table 3) using the estimated dynamic sticking efficiency of the flume and the often assumed static value of sticking efficiency $(\alpha=1)$. In both the dynamic and static calculations of $C_{\mathrm{cr}}$, cellular physiology precluded a critical concentration of Thalassiosira pseudonana cells during the initiation and maintenance phases of the bloom. In essence, the size of the bloom was limited by physiological constraints and not physical aggregation processes during the initiation and maintenance phases. However, after the physiological aging of T. pseudonana, physical coagulation processes dominated the senescence phase of the bloom as the critical concentration of algal particles was reached. During the senescence phase, as the concentration of algal particles fell below the critical concentration because of the high sticking efficiency, coagulation dynamics played an increasingly important role in the export flux from the bloom.

Consequently, phytoplankton blooms modeled using a dynamic sticking efficiency have similar dynamics to natural blooms. Using a dynamic sticking efficiency, similar to the estimated values of this study, increases the critical concentration such that cellular physiology is the bloom-limiting factor during bloom initiation and maintenance phases. The increased sticking efficiency attained during the later stages of a bloom will shift the bloom dynamics from physiological to physical forcing. Simulating phytoplankton dynamics that shift a bloom from being physiologically limited to physically controlled results in simulated phytoplankton blooms that share the pulsed nature of particulate flux that is characteristic of sediment trap data from both the Pacific Ocean (Karl et al. 1996) and the Atlantic Ocean (Steinberg et al. 2001). When considering models of export flux, such as the one used in this study, it is crucial to note that changes in the duration of each bloom phase primarily affects the degree to which the particle flux of each phase approaches a steady state. For example, when primary productivity is low but sustained, such as in oligotrophic systems, the small but constant flux of particles from the surface ocean approximate a steady state where primary production is more or less balanced by export flux from the surface. Comparatively, the nature of particle formation and mesopelagic processes are responsible for ecosystems having a pulsed export flux that can be 26 to $35 \%$ more efficient compared to an ecosystem having a constant 'rain' of particles out of the euphotic zone (Buesseler et al. 2007). 


\section{CONCLUSIONS}

Using a new method and an analysis based on longstanding theoretical arguments, the sticking efficiency of algal cells has been estimated in situ at low shear. Simultaneously, changes in cell physiology provided a foundation for understanding the role of intra- and inter-cellular processes in driving phytoplankton bloom dynamics. These data reveal the importance of phytoplankton physiology in the downward flux of carbon during phytoplankton bloom succession. From the perception of stress by a single cell to large biogeochemical processes in the ocean, cellular mechanisms that regulate phytoplankton growth and mortality act as a framework for the interplay between the biology and physics of a bloom and its subsequent effects on carbon export in the ocean. Given the importance of sticking efficiency as a link between cell physiology and coagulation processes and the resultant export flux from a bloom, an improved understanding of the factors regulating the variability of sticking efficiency should be the focus of future studies.

Acknowledgements. This work was supported by grants from MURI (N00014-06-1-0739) and BSF (BSF-20022396). We are grateful for the help provided by Char Fuller and Piotr Nawrot at the IMCS Annular Flume Facility. Felisa Wolfe-Simon kindly shared her TpMnSOD antibodies for this research. For contributing discussion, comments and suggestions, we thank K. Bidle, P. Cermeño, H. Dam, P. Falkowski, J. Hencken, and E. Leonardis. Foremost, we are indebted to the 4 anonymous reviewers whose constructive criticism and advice were instrumental in producing the final version of this manuscript.

\section{LITERATURE CITED}

Ackleh AS, Hallam TG, Muller-Landau HC (1995) Estimation of sticking and contact efficiencies in aggregation of phytoplankton: the 1993 SIGMA tank experiment. Deep-Sea Res II 42:185-201

Alldredge AL, Gotschalk CC (1988) In situ settling behavior of marine snow. Limnol Oceanogr 33:339-351

Alldredge AL, Gotschalk CC (1989) Direct observations of the mass flocculation of diatom blooms: characteristics, settling velocities and formation of diatom aggregates. Deep-Sea Res 36:159-171

Alldredge AL, McGillivary P (1991) The attachment probabilities of marine snow and their implications for particle coagulation in the ocean. Deep-Sea Res 38:431-443

Alldredge AL, Granata TC, Gotschalk CC, Dickey TD (1990) The physical strength of marine snow and its implications for particle disaggregation in the ocean. Limnol Oceanogr 35:1415-1428

Alldredge AL, Gotschalk CC, Passow U, Riebesell U (1995) Mass aggregation of diatom blooms: insights from a mesocosm study. Deep-Sea Res II 42:9-27

Berman-Frank I, Bidle KD, Haramaty L, Falkowski PG (2004) The demise of the marine cyanobacterium, Trichodesmium spp., via an autocatalyzed cell death pathway. Limnol Oceanogr 49:997-1005
Berman-Frank I, Rosenberg G, Levitan O, Haramaty L, Mari X (2007) Coupling between autocatalytic cell death and transparent exopolymeric particle production in the marine cyanobacterium Trichodesmium. Environ Microbiol 9:1415-1422

Bidle KD, Falkowski PG (2004) Cell death in planktonic photosynthetic microorganisms. Nat Rev Microbiol 2:643-655

Bidle KD, Haramaty L, Barcelos e Ramos J, Falkowski PG (2007) Viral activation and recruitment of metacaspases in the unicellular coccolithophore, Emiliania huxleyi. Proc Natl Acad Sci 104:6049-6054

Brunk BK, Koch DL, Lion LW (1998) Observations of coagulation in isotropic turbulence. J Fluid Mech 371:81-107

$>$ Buesseler KO, Lamborg CH, Boyd PW, Lam PJ and others (2007) Revisiting carbon flux through the ocean's twilight zone. Science 316:567-570

Busch PL, Stumm W (1968) Chemical interactions in the aggregation of bacteria bioflocculation in waste treatment. Environ Sci Technol 2:49-53

Butow BJ, Wynne D, Tel-Or E (1997) Superoxide dismutase activity in Peridinium gatunense in Lake Kinneret: effect of light regime and carbon dioxide concentration. J Phycol 33:787-793

Dam HG, Drapeau DT (1995) Coagulation efficiency, organicmatter glues and the dynamics of particles during a phytoplankton bloom in a mesocosm study. Deep-Sea Res II 42:111-123

Drapeau DT, Dam HG, Grenier G (1994) An improved flocculator design for use in particle aggregation experiments. Limnol Oceanogr 39:723-729

Engel A (2000) The role of transparent exopolymer particles (TEP) in the increase in apparent particle stickiness $(\alpha)$ during the decline of a diatom bloom. J Plankton Res 22: 485-497

Engel A (2004) Distribution of transparent exopolymer particles (TEP) in the northeast Atlantic Ocean and their potential significance for aggregation processes. Deep-Sea Res I 51:83-92

Field CB, Behrenfeld MJ, Randerson JT, Falkowski PG (1998) Primary production of the biosphere: integrating terrestrial and oceanic components. Science 281:237-240

Fowler SW, Knauer GA (1986) Role of large particles in the transport of elements and organic compounds through the oceanic water column. Deep-Sea Res 16:147-194

Gelbard F, Tambour Y, Seinfeld JH (1980) Sectional representations for simulating aerosol dynamics. J Colloid Interface Sci 76:541-556

Gibbs JR (1982) Floc stability during Coulter counter analysis. J Sediment Petrol 52:657-670

Gorbunov MY, Falkowski PG (2004) Fluorescence induction and relaxation (FIRe) technique and instrumentation for monitoring photosynthetic processes and primary production in aquatic ecosystems. In: van der Est A, Bruce D (eds) Photosynthesis: fundamental aspects to global perspectives. International Society of Photosynthesis. Allen Press, Lawrence, KS (CD-ROM)

Gotschalk CC, Alldredge AL (1989) Enhanced primary production and nutrient regeneration within aggregated marine diatoms. Mar Biol 103:119-129

Hansen JLS, Kiørboe T (1997) Quantifying interspecific coagulation efficiency of phytoplankton. Mar Ecol Prog Ser 159: 75-79

Hentschel BT (2004) Sediment resuspension and boundary layer flow dramatically increase the growth rates of interface-feeding spionid polychaetes. J Mar Syst 49:209-224

Hill PS (1992) Reconciling aggregation theory with observed vertical fluxes following phytoplankton blooms. J Geophys Res C 97:2295-2308 
Hill PS, Nowell ARM (1990) The potential role of large, fastsinking particles in cleaning nepheloid layers: discussion. Philos Trans R Soc Lond A 331:103-117

Hunt JR (1980) Coagulation in continuous particle size distributions: theory and experimental verification. $\mathrm{PhD}$ thesis, California Institute of Technology, Pasadena, CA

Hunt JR (1982) Particle dynamics in seawater: implications for predicting the fate of discharged particles. Environ Sci Technol 16:303-309

Jackson GA (1990) A model of the formation of marine algal flocs by physical coagulation processes. Deep-Sea Res 37:1197-1211

Jackson GA (1995) Coagulation of marine algae. In: Huang CP, O'Melia CR, Morgan JJ (eds) Aquatic chemistry: interfacial and interspecies processes. American Chemical Society, Washington, DC, p 203-217

Jackson GA (2005) Coagulation theory and models of oceanic plankton aggregation. In: Droppo I, Leppard G, Liss S, Milligan $\mathrm{T}$ (eds) Flocculation in natural and engineered environmental systems. CRC Press, Boca Raton, FL, p 271-292

Jackson GA, Burd AB (1998) Aggregation in the marine environment. Environ Sci Technol 32:2805-2814

Jackson GA, Lochmann SE (1992) Effect of coagulation on nutrient and light limitation of an algal bloom. Limnol Oceanogr 37:77-89

Jackson GA, Lochmann SE (1993) Modeling coagulation in marine ecosystems. In: Buffle, J, van Leeuwen HP (eds) Environmental particles, Vol 2. Lewis Publishers, Boca Raton, FL, p 387-414

Jackson GA, Maffione R, Costello DK, Alldredge AL, Logan BE, Dam HG (1997) Particle size spectra between $1 \mu \mathrm{m}$ and $1 \mathrm{~cm}$ at Monterey Bay determined using multiple instruments. Deep-Sea Res I 44:1739-1767

Jackson GA, Waite A, Boyd PW (2005) Role of algal aggregation in vertical carbon export during SOIREE and in other low biomass environments. Geophys Res Lett 32:1-4

Karl DM, Christian JR, Dore JE, Hebel DV, Letelier RM, Tupas LM, Winn CD (1996) Seasonal and interannual variability in primary production and particle flux at Station ALOHA. Deep-Sea Res II 43:539-568

Karp-Boss L, Jumars PA (1998) Motion of diatoms chains in steady shear flow. Limnol Oceanogr 43:1767-1773

Kiørboe T, Hansen JLS (1993) Phytoplankton aggregate formation: observations of patterns and mechanisms of cell sticking and the significance of exopolymeric material. J Plankton Res 15:993-1018

Kiørboe T, Andersen KP, Dam HG (1990) Coagulation efficiency and aggregate formation in marine phytoplankton. Mar Biol 107:235-245

Kiørboe T, Lundsgaard C, Olesen M, Hansen JLS (1994) Aggregation and sedimentation processes during a spring phytoplankton bloom: a field experiment to test coagulation theory. J Mar Res 52:297-323

Kiørboe T, Tiselius P, Mitchell-Innes B, Hansen JLS, Visser AW, Mari X (1998) Intensive aggregate formation with low vertical flux during an upwelling-induced bloom. Limnol Oceanogr 43:104-116

Kolber ZS, Falkowski PG (1993) Use of active fluorescence to estimate phytoplankton photosynthesis in situ. Limnol Oceanogr 38:1646-1665

$>$ Li X, Logan BE (1995) Size distributions and fractal properties of particles during a simulated phytoplankton bloom in a mesocosm. Deep-Sea Res II 42:125-138

Logan BE, Passow U, Alldredge AL, Grossart H, Simon M (1995) Rapid formation and sedimentation of large aggregates is predictable from coagulation rates (half-lives) of transparent exopolymer particles (TEP). Deep-Sea Res II 42:203-214
Martin JH, Knauer GA, Karl DM, Broenkow WW (1987) VERTEX: carbon cycling in the northeast Pacific. Deep-Sea Res 34:267-285

McCave IN (1984) Size spectra and aggregation of suspended particles in the deep ocean. Deep-Sea Res 31:329-352

Moeseneder MM, Herndl GJ (1995) Influence of turbulence on bacterial production in the sea. Limnol Oceanogr 40: 1466-1473

$>$ Myklestad S (1974) Production of carbohydrates by marine planktonic diatoms. I. Comparison of nine different species in culture. J Exp Mar Biol Ecol 15:261-274

Passow U (2000) Formation of transparent exopolymer particles, TEP, from dissolved precursor material. Mar Ecol Prog Ser 192:1-11

Passow U (2002) Production of transparent exopolymer particles (TEP) by phyto- and bacterioplankton. Mar Ecol Prog Ser 236:1-12

Passow U, Alldredge AL (1995a) A dye binding assay for the spectrophotometric measurement of transparent exopolymer particles (TEP). Limnol Oceanogr 40:1326-1335

Passow U, Alldredge AL (1995b) Aggregation of a diatom bloom in a mesocosm: the role of transparent exopolymer particles (TEP). Deep-Sea Res II 42:99-109

Passow U, Alldredge AL, Logan BE (1994) The role of particulate carbohydrate exudates in the flocculation of diatom blooms. Deep-Sea Res I 41:335-357

Petersen JE, Sanford LP, Kemp WM (1998) Coastal plankton responses to turbulent mixing in experimental ecosystems. Mar Ecol Prog Ser 171:23-41

Porter KG, Feig YS (1980) The use of DAPI for identifying and counting aquatic microflora. Limnol Oceanogr 25:943-948

Prieto L, Ruiz J, Echevarria F, Garcia CM and others (2002) Scales and processes in the aggregation of diatom blooms: high time resolution and wide size range records in a mesocosm study. Deep-Sea Res 49: 1233-1253

> Riebesell U (1991) Particle aggregation during a diatom bloom. I. Physical aspects. Mar Ecol Prog Ser 69:273-280

Riebesell U (1992) The formation of large marine snow and its sustained residence in surface waters. Limnol Oceanogr 37:63-76

Riedl SJ, Shi YG (2004) Molecular mechanisms of caspase regulation during apoptosis. Nat Rev Mol Cell Biol 5:897-907

Segovia M, Haramaty L, Berges JA, Falkowski PG (2003) Cell death in the unicellular chlorophyte Dunaliella tertiolecta. A hypothesis on the evolution of apoptosis in higher plants and metazoans. Plant Physiol 132:99-105

Smith DC, Simon M, Alldredge AL, Azam F (1992) Intense hydrolytic enzyme activity on marine aggregates and implications for rapid particle dissolution. Nature 359:139-142

Smith DC, Steward GF, Long RA, Azam F (1995) Bacterial mediation of carbon fluxes during a diatom bloom in a mesocosm. Deep-Sea Res II 42:75-97

Steinberg DK, Carlson CA, Bates NR, Johnson RJ, Michaels AF, Knap AH (2001) Overview of the US JGOFS Bermuda Atlantic Time-series Study (BATS): a decade-scale look at ocean biology and biogeochemistry. Deep-Sea Res II 48: 1405-1447

Turner JT (2002) Zooplankton fecal pellets, marine snow and sinking phytoplankton blooms. Aquat Microb Ecol 27:57-102

Vardi A, Berman-Frank I, Rozenberg T, Hadas O, Kaplan A, Levine A (1999) Programmed cell death of the dinoflagellate Peridinium gatunense is mediated by $\mathrm{CO}_{2}$ limitation and oxidative stress. Curr Biol 9:1061-1064

Vardi A, Eisenstadt D, Murik O, Berman-Frank I, Zohary T, Levine A, Kaplan A (2007) Synchronization of cell death in a dinoflagellate population is mediated by an excreted thiol protease. Environ Microbiol 9:360-369 
Waite A, Nodder S (2001) The effect of in situ iron addition on the sinking rates and export flux of Southern Ocean diatoms. Deep-Sea Res II 48:2635-2654

Waite A, Olson RJ, Dam HG, Passow U (1995) Sugar-containing compounds on the cell surfaces of marine diatoms measured using concanavalin A and flow cytometry. J Phycol 31:925-933

Editorial responsibility: Graham Savidge,

Portaferry, UK
Waite A, Gallager S, Dam HG (1997) New measurements of phytoplankton aggregation in a flocculator using videography and image analysis. Mar Ecol Prog Ser 155:77-88

Wolfe-Simon F, Starovoytov V, Reinfelder JR, Schofield O, Falkowski PG (2006) Localization and role of manganese superoxide dismutase in a marine diatom. Plant Physiol 142:1701-1709

Submitted: August 1, 2007; Accepted: November 17, 2007 Proofs received from author(s): January 9, 2008 